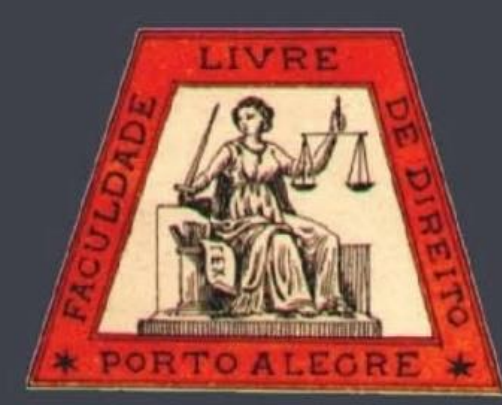

\title{
Empresa de Tendência: um estudo comparado entre o Mercosul e a União Europeia
}

Tendency Company: a comparative study between Mercosur and the European Union

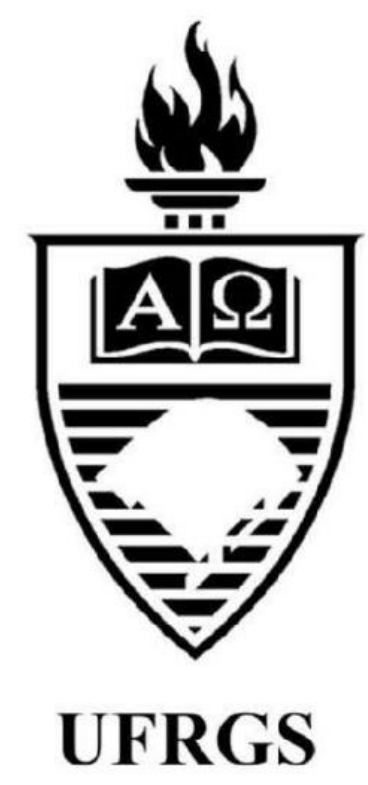

\author{
Luís Alexandre Carta Winter \\ Pontifícia Universidade Católica do Paraná \\ Natalia Munhoz Machado Prigol \\ Pontifícia Universidade Católica do Paraná
}




\title{
Empresa de Tendência: um estudo comparado entre o Mercosul e a União Europeia
}

\author{
Tendency Company: a comparative study between Mercosur and the European Union
}

Luís Alexandre Carta Winter ${ }^{*}$

Natalia Munhoz Machado Prigol ${ }^{* *}$

\section{REFERÊNCIA}

WINTER, Luís Alexandre Carta; PRIGOL, Natalia Munhoz Machado. Empresa de Tendência: um estudo comparado entre o Mercosul e a União Europeia. Revista da Faculdade de Direito da UFRGS, Porto Alegre, n. 36, p. 183-206, ago. 2017.

\section{RESUMO}

Objetiva-se analisar o conceito e a aplicação jurídica do instituto denominado "Empresa de Tendência" na União Europeia e no Mercosul. A utilização do conceito implica na colisão de direitos fundamentais entre o empregado (liberdade consciência) e o empregador (liberdade gerência da empresa), a qual deve ser resolvida através da ponderação dos bens jurídicos conflitantes. Os estudos de casos demonstram que na União Europeia o conceito já está consolidado. No MERCOSUL, de modo diverso, o conceito carece de certeza jurídica, havendo muita discrepância com relação à sua aplicabilidade até mesmo dentro de um único país. Ao final, propõe-se a retificação da Declaração Sociolaboral no intuito de promover uma harmonização da legislação dos Estados-Membros a respeito do tema. Utilizar-se-á dos métodos dedutivos e comparativos para elaboração do estudo.

\section{PALAVRAS-CHAVE}

Empresa de tendência. MERCOSUL. União Europeia. Harmonização legislative. Países do MERCOSUL.

\begin{abstract}
The objective of this paper is to analyze the concept and legal application of the so-called "Tendency Company" in the European Union and in Mercosur. The concept implies collision of fundamental rights between the employee (freedom of conscience) and the employer (freedom of management of the company), which must be resolved by weighing the conflicting legal rights. The case studies show that in the European Union the concept is already consolidated. In MERCOSUR, the concept lacks legal certainty, and there is much discrepancy regarding its applicability even within the same country. Finally, it is proposed to rectify the Socio-Labor Declaration in order to promote a harmonization of the legislation of the Member-States regarding the subject. The deductive and comparative methods will be used to elaborate the study.
\end{abstract}

\section{KEYWORDS}

Tendency Company. MERCOSUR. European Union. Legislative harmonization. MERCOSUR countries.

\section{SUMÁRIO}

Introdução. 1. Conceito de "Empresas ou Organizações de Tendência". 2. União Europeia. 3. Mercosul. 3.1. Argentina. 3.2. Brasil. 3.3. Uruguai. 3.4. Paraguai. Conclusão. Referência.

\footnotetext{
* Professor titular da Faculdade de Direito da PUCPR. Doutor em Integração da América pela USP/PROLAM.

${ }^{* * *}$ Mestranda em Direito pela PUCPR.
} 


\section{INTRODUÇÃO}

O estudo objetiva analisar comparativamente o tratamento legislativo, doutrinário e jurisprudencial da União Europeia e do Mercosul a respeito do instituto jurídico das empresas de tendência.

$\mathrm{Na}$ União Europeia, o conceito é bem definido pela doutrina e jurisprudência, e sua aplicação pelos Estados-Membros ocorre sem maiores dificuldades. Diante deste cenário, exsurge a questão se, no Mercosul, o instituto das empresas de tendência é tratado com o mesmo amadurecimento e uniformidade como o é na União Europeia?

Para responder ao questionamento, inicialmente será apresentado o conceito de "empresas de tendência". Em seguida, analisarse-á o tratamento jurídico do tema em sede de União Europeia através da análise de julgados proferidos pelo Tribunal Europeu de Direitos Humanos.

Em seguida, adentrará individualmente em cada Estado-Membro do Mercosul (Argentina, Brasil, Uruguai e Paraguai), expondo os principais aspectos com relação aos respectivos ordenamentos jurídicos que possuem relevância para o estudo, bem como apresentando julgados proferidos pelos tribunais internos para demonstrar como a questão é tratada.

Ao final, será possível responder ao questionamento comparando os blocos em análise. Por se tratar de um artigo propositivo, será apresentado uma proposta de retificação da Declaração Sociolaboral do Mercosul, visando a harmonização da legislação dos EstadosMembros com relação a aplicação do conceito das empresas de tendência.

Utilizar-se do método dedutivo, porque o estudo parte do geral consolidado (União Europeia) para o particular (Mercosul) e, comparativo porque para cada Estado-Membro apresenta-se estudos de caso.

\section{CONCEITO DE "EMPRESAS OU ORGANIZAÇÕES DE TENDÊNCIA OU IDEOLÓGICAS ${ }^{1}$ "}

A celebração de um contrato de trabalho não pressupõe a privação de direitos personalíssimos dos empregados, cabendo ao empregador assegurar a todos um tratamento igualitário, proporcionar um ambiente de trabalho neutro, coibir manifestações discriminatórias que os afetem injustificadamente, além de garantir o amplo exercício à liberdade de consciência. Neste sentido a Organização Internacional do Trabalho (OIT) publicou a Convenção n. ${ }^{\circ}$ 111, estabelecendo em seu artigo $1^{\circ}$ que o termo "discriminação" compreende "toda distinção, exclusão ou preferência fundada na raça, cor, sexo, religião, opinião política, ascendência nacional ou origem social, que tenha por efeito destruir ou alterar a igualdade de oportunidade ou de tratamento em matéria de emprego ou profissão",2.

No entanto, a inserção do empregado no ambiente de trabalho do empresário traz consequências nas quais o exercício de direitos fundamentais deve se conciliar com os interesses legítimos empresariais ${ }^{3}$. Ademais, a depender do tipo de função que o trabalhador se obrigou a desempenhar e a natureza particular dos

1 O termo mais utilizado no Brasil é "Empresas de Tendência", mas, dentro do Mercosul a questão por vezes é tratada como "Organizações Ideológicas", razão pela qual se optou por utilizar ambos os termos como sinônimos.

2 ORGANIZAÇÃO INTERNACIONAL DO TRABALHO. Convenção $n^{o}$ 111. Disponível em: <http://www.oit.org.br/node/472>. Acesso em 15/01/2017.

${ }^{3}$ CARDO, Ivan Antonio Rodriguez. La incidencia de la libertad religiosa en la relación de trabajo desde la perspectiva del tribunal constitucional español. Direitos Fundamentais \& Justiça, n. 15, p. 17-39, abril/junho, 2011. Disponível em: <http://www.dfj.inf.br/Arquivos/PDF_Livre/15_Dout_Estr angeira_1.pdf $>$. Acesso em 31/01/2017. 
interesses da entidade empregadora, os direitos do empregado serão sujeitos a certas limitações, fruto de uma cuidadosa ponderação de bens jurídicos ${ }^{4}$.

Exemplificando, um professor de religião de uma Universidade Católica, que tem como função a propagação de uma ideologia religiosa, não pode conceder entrevistas manifestando o seu descontentamento com as doutrinas cristãs, afirmando-se ateu, mesmo que isso ocorra fora do ambiente laboral. Tal comportamento gera consequências negativas para a própria organização, prejudicando a sua imagem, o que pode ensejar a dispensa por justa causa ${ }^{5}$.

$\mathrm{Ou}$ ainda, o pastor evangélico que prega durante o seu culto o dever dos cônjuges à fidelidade, mas não vive aquilo que doutrina e mantém uma relação extraconjugal. Este comportamento vai de encontro às regras de fé da organização, colocando em risco a pureza doutrinal, sendo potencial fator de desunião da membresia.

Os dois casos hipotéticos demonstram a existência de um conflito de direitos fundamentais entre sujeitos (empregador e empregado) em razão da vinculação de uma ideologia dentro do ambiente de trabalho. Diante desta controvérsia, pergunta-se: como compatibilizar direitos diametralmente opostos, que não podem ser resolvidos com uma mera aplicação positiva da lei, sem que ocorra infração ao que preceitua o artigo $1^{\circ}$ da Convenção 111 , OIT - acima descrito? É sob esta perspectiva que se analisa o instituto jurídico das "Empresas ou Organizações de Tendência”.

\footnotetext{
4 REIS, Raquel Tavares dos. Direitos, liberdades de garantias da pessoa do trabalhador despedido em razão da sua conduta extra-laboral. Revista Gestão $e$ Desenvolvimento, 10 (2001), p. 95-127.

5 A exemplo do que ocorreu na Espanha. ESPANHA. Tribunal Constitucional da Espanha. STC 47/1985. Disponível em: <http://hj.tribunalconstitucional.es/es/Resolucion/Show/42 7>. Acesso em 05/02/2017.
}

Entende-se por organização de tendência aquelas empresas que têm por finalidade estar a serviço, cultivo ou difusão de uma ideologia amplamente reconhecida ${ }^{6}$. Assim, o elemento caracterizador das empresas de tendência é o fato de servir para um fim ideológico de mundo, inspirada em valores ou ideias claramente reconhecidos ${ }^{7}$.

Tais empresas se diferem das demais porque desenvolvem como atividade precípua a exteriorização de preceitos ideológicos, que vão além de uma simples política interna da empresa, sendo a própria razão de ser da instituição, que goza, inclusive, de autonomia perante o estado ${ }^{8}$.

Existem duas correntes que definem as empresas de tendência: (i) a primeira, em sentido estrito, defende que são empresas ideológicas os partidos políticos, as organizações sindicais e as confissões religiosas; (ii) a segunda, em sentido amplo ou global, entende que podem ser consideradas empresas de tendência as organizações destinadas para fins políticos, sindicais, confessionais, educativos e artísticos ${ }^{9}$. A divergência possui pouca relevância para o debate, visto que na prática qualquer empresa que tenha como objetivo precípuo a exteriorização de uma ideologia amplamente

\footnotetext{
6 REIS, Raquel Tavares dos. Direitos, liberdades de garantias da pessoa do trabalhador despedido em razão da sua conduta extra-laboral. Revista Gestão $e$ Desenvolvimento, 10 (2001), p. 95-127.

7 SÁNCHEZ, Belén Salanova. El principio de no discriminación por motivos religiosos y de convicción en el ámbito laboral: El acomodamiento razonable. Trabajo fim de master, 2013. Universidad Zaragoza. Disponível em: <http://zaguan.unizar.es/record/12435/files/TAZTFM-2013-862.pdf >. Acesso em 14/01/2017.

8 SÁNCHEZ, Belén Salanova. El principio de no discriminación por motivos religiosos y de convicción en el ámbito laboral: El acomodamiento razonable. Trabajo fim de master, 2013. Universidad Zaragoza. Disponível em: <http://zaguan.unizar.es/record/12435/files/TAZTFM-2013-862.pdf >. Acesso em 14/01/2017.

9 TENA, Angel Luis de Val. Las empresas de tendencia ante el derecho del trabajo: libertad ideológica y contrato de trabajo. p. 179 . Disponível em: <http://dialnet.unirioja.es/servlet/articulo?codigo=229694> . Acesso em 22/09/2015.
} 
reconhecida será caracterizada como empresa de tendência.

Sua criação advém de um segmento da doutrina e da jurisprudência que analisam a integração de ideologias dentro do ambiente de trabalho, tendo sido primeiramente recepcionada pelo direito alemão, através do instituto denominado Tendenzbetriebe. À época, o conceito era utilizado para limitar ou excluir certos direitos de trabalhadores em determinadas empresas onde a participação deles era incompatível com a natureza institucional da própria empresa ${ }^{10}$.

Atualmente, é utilizado não apenas para limitar ou excluir certos direitos dos empregados, mas, também, para exigir que tais empregados hajam de acordo com os preceitos de ética e moral propagados pela organização, sob pena de serem dispensando com justa causa.

Deste modo, o objetivo com a criação do instituto é o de proteger a imagem da empresa de atos comportamentais temerários de seus empregados que possam gerar efeitos negativos para a própria organização, a exemplo do professor de religião e do pastor evangélico acima citados. Inclusive, a respeito defende Jonatas Machado que, "nem quando se verifique a existência de um vínculo laboral se deixará de chegar a um resultado semelhante, no caso do incumprimento de deveres especiais de lealdade e de conduta, não arbitrários nem desiguais, susceptível de afetar e desacreditar a imagem moral externa da organização". ${ }^{11}$

A aplicação do conceito implica uma zona de conflito em razão da mitigação de direitos: de um lado, a figura do empregador, que o invoca para proteger a imagem da sua empresa e, de

\footnotetext{
10 VIVES, Juan Martin. Las instituciones religiosas del tercer sector como empresas de tendencia. Revista de Estudos e Pesquisas Avançadas do Terceiro Setor (REPATS), Brasília, v. 1, n. 1, p.1-19, Jul-Dez, 2014.

11 MACHADO, Jónatas Eduardo Mendes. Liberdade religiosa numa comunidade constitucional inclusiva dos direitos da verdade aos direitos dos cidadãos. Coimbra: Coimbra Editora, 1996, p. 271.
}

outro, a figura do empregado, que o rejeita arguindo o direito à liberdade de consciência, foro íntimo e vida privada.

Diante da controvérsia, faz-se necessária uma cuidadosa ponderação dos bens jurídicos em voga ${ }^{12} 13$, sendo que, em se tratando de empregados inseridos neste modelo de empresa e, desde que ocupantes de cargos de proeminência ou que exteriorizam a própria tendência (ex. professor, pastor, político, etc.) poderão sofrer limitações aos seus direitos fundamentais, em especial aos da liberdade de consciência e expressão. Assim, ocorre uma atenuação dos direitos dos empregados em prol da preservação da imagem da organização de tendência.

Ressalva-se que, em se tratando de cargos que não cumprem fins propriamente ideológicos, apesar de possuir uma estreita vinculação com a ideologia, é vedada qualquer distinção com relação a religião, pensamento ou afiliação política, porque é absolutamente irrelevante para a relação de trabalho ${ }^{14}$. Exemplificando-se, um jardineiro de uma empresa de tendência não poderá sofrer limitações aos seus direitos porque não exerce funções diretamente ligadas à ideologia da instituição.

Em suma, serão consideradas empresas de tendência aquelas que servirem para a difusão de um determinado sistema de valores, crenças ou ideais claramente reconhecidos ${ }^{15}$.

\footnotetext{
${ }^{12}$ BOBBIO, Norberto. A era dos direitos. Rio de Janeiro: Elsevier, 2004, p. 187.

${ }^{13}$ ALEXY, Robert. Teoria dos direitos fundamentais. 2. ed. São Paulo: Malheiros Editores, 2011, p. 95.

${ }^{14}$ CORREA, Fernando Gustavo Abarca. Los derechos fundamentales del trabajador em la empresa. Universidad de Chile Faculdad de Derecho Departamento de Derecho Del Trabajo Y Seguridade Social. Disponível em: http://repositorio.uchile.cl/bitstream/handle/2250/107311/a barca_f.pdf?sequence=3. Acesso em 12/01/2017.

15 SÁNCHEZ, Belén Salanova. El principio de no discriminación por motivos religiosos y de convicción en el ámbito laboral: El acomodamiento razonable. Trabajo fim de master, 2013. Universidad Zaragoza. Disponível em: $\quad$ http://zaguan.unizar.es/record/12435/files/TAZTFM-2013-862.pdf>. Acesso em 14/01/2017.
} 
Como o conceito trabalha com a ideia da colisão de direitos, caberá ao aplicador do direito identificar os valores e princípios que devem ser conciliados, ponderando-os com base nos princípios da razoabilidade e proporcionalidade no intuito de encontrar a melhor solução para o caso em análise ${ }^{16} \mathrm{e}$, em se constatando tratar-se de uma empresa de tendência, mitigar os direitos individuais dos empregados em prol da própria organização.

Posto isto, passa-se a análise de como o conceito é tratado na União Europeia e no Mercosul.

\section{UNIÃO EUROPEIA}

$\mathrm{Na}$ União Europeia, o conceito de Empresas de Tendência é bem definido pela doutrina e jurisprudência, e sua aplicação pelos Estados-Membros ocorre sem maiores dificuldades.

Essa maturidade tem por origem a existência de duas Diretivas, as quais tem efeito vinculante junto aos Estados-Membros ${ }^{17}$. São elas: a primeira, Diretiva 94/45/CE do Conselho de Setembro de 1994 e, a segunda, Diretiva 2000/78/CE do Conselho de 27 de novembro de 2000. Registre-se que, apesar de impor aos estados as obrigações dispostas nas Diretivas, os mesmos gozam de autonomia no que concerne à forma e o meio de execução para atingimento destes resultados.

\footnotetext{
${ }^{16}$ DWORKIN, Robert. Uma questão de princípio. 2. ed. São Paulo: Martins Fontes, 2005, p. 15.

${ }^{17}$ UNIÃO EUROPEIA. Tratado sobre o funcionamento da União Europeia, 26/10/2012. Artigo 288: “A diretiva vincula o Estado-Membro destinatário quanto ao resultado a alcançar, deixando, no entanto, às instâncias nacionais a competência quanto à forma e aos meios". Disponível em: $<$ http://eur-lex.europa.eu/legalcontent/pt/TXT/?uri=CELEX\%3A12012E\%2FTXT>. Acesso em 06/02/2017. Artigo 288: “A diretiva vincula o Estado-Membro destinatário quanto ao resultado a alcançar, deixando, no entanto, às instâncias nacionais a competência quanto à forma e aos meios".
}

A primeira das Diretivas é precursora com relação ao tema em sede de União Europeia. Em linhas gerais, possibilitou que empresas com finalidades de orientação ideológica (empresas de tendência) adotassem disposições especiais nas relações que mantinham, desde que para assegurar o melhor desempenho da própria organização. Veja-se a disposição original do artigo $8^{18}$ a respeito:

Cada Estado-membro pode adoptar disposições especiais a favor da direção central das empresas estabelecidas no seu território que tenham direta e principalmente finalidades de orientação ideológica relacionadas com a informação e a expressão de opiniões, desde que, à data de adopção da presente diretiva, essas disposições especiais já existam na legislação nacional.

A segunda Diretiva, considerada mais relevante para o tema, estabelece um quadro geral de igualdade de tratamento no emprego, coíbe o tratamento discriminatório e, prevê situações em que é possível justificar um tratamento diferente quando constitua um requisito genuíno e determinante para a atividade profissional, e desde que o objetivo seja legitimo, o requisito proporcional e os meios adequados e necessários. É neste sentido a disposição do artigo $4^{\circ}$ da referida Diretiva:

1. Sem prejuízo do disposto nos n. ${ }^{\circ} 1$ e 2 do artigo $2^{\circ}$, os Estados-Membros podem prever que uma diferença de tratamento baseada numa característica relacionada com qualquer dos motivos de discriminação referidos no artigo $1^{\circ}$ não constituirá discriminação sempre que, em virtude da natureza, da atividade profissional em causa ou do contexto da sua execução, essa característica constitua um requisito essencial e determinante para o exercício desta atividade, na condição de o objetivo ser legitimo e o requisito proporcional. 2. [...] No caso das atividades profissionais de igrejas e de outras organizações públicas ou privadas cuja ética seja

18 UNIÃO EUROPEIA. Diretiva 94/45/CE do Conselho, de 22 de Setembro de 1994. Disponível em: <http://eurlex.europa.eu/legalcontent/PT/TXT/?uri=CELEX:31994L0045>. Acesso em 02/02/2017. 
baseada na religião ou em convicções, uma diferença de tratamento baseada na religião ou nas convicções de uma pessoa não constitua discriminação sempre que, pela natureza dessas atividades ou pelo contexto da sua execução, a religião ou as convicções constituam um requisito profissional essencial, legítimo e justificado no âmbito da ética da organização.

Deste modo, a Diretiva permite que, em razão da natureza da atividade profissional o empregador exija determinados comportamentos de seus empregados que se assemelhem aos padrões de ética e moral pregados pela organização, sendo esta a previsão das "empresas de tendência".

Tal prerrogativa concedida aos empregadores de tendência é limitada as atividades que tenham um papel essencial no âmbito da ética da organização, ou seja, apenas aqueles empregados que exerçam atividades diretamente vinculadas com a ideologia da organização poderão sofrer restrições aos seus direitos, no intuito de preservar a imagem da própria organização.

Da mesma forma, devem os empregados compartilhar das mesmas ideologias da empresa a que estão vinculados para assegurar que as obrigações assumidas sejam integralmente cumpridas e, acima de tudo, para evitar que um comportamento deste empregado fora do horário e ambiente de trabalho comprometa ou coloque em risco a credibilidade da organização ${ }^{19}$.

Diferente não poderia ser. Exemplificase: não é crível que um partido político que propague ideologias de cunho liberal contrate um empregado, para exercer um cargo de proeminência, que comungue de ideias conservadoras. É evidente que tal empregado

\footnotetext{
${ }^{19}$ GALLEGO, Francisco Javier Calvo; LÓPEZ, María Fernanda Fernández. Directive 2000/78/EC and the proibition of discrimination based on religion. University of Sevilla and Huelva. Disponível em: <http://www.eracomm.eu/oldoku/Adiskri/09_Religion/2005_CalvoGallego 1-EN.pdf $\geq$. Acesso em 23/01/2017.
}

não conseguiria exercer plenamente a sua função em razão do conflito de ideologias.

Quando o conceito é arguido por algum Estado-Membro, o conflito jurídico que surge se articula sobre os seguintes direitos: o direito do cidadão à liberdade de consciência e expressão (artigo $9^{\circ}$, Convenção Europeia de Direitos Humanos) e, de outro lado, o direito à liberdade de associação que pressupõe a existência de uma relativa autonomia do grupo (artigo $11^{\circ}$ da Convenção Europeia de Direitos Humanos) ${ }^{20}$. Registre-se, inclusive, que todos os EstadosMembros possuem julgados que aplicam o conceito nas decisões proferidas pelos tribunais internos, razão pela qual se optou por analisar precedentes do bloco como um todo, para não deixar o estudo massivo.

$\mathrm{O}$ primeiro precedente proferido pelo Tribunal Europeu de Direito Humanos que decidiu fazer prevalecer o direito do empregador sobre o direito à liberdade de consciência do empregado se tratou do seguinte caso: um médico empregado alemão de um hospital católico também alemão, cujo contrato estipulava que o mesmo deveria agir com lealdade e de acordo com os princípios católicos, assinou uma carta defendendo a prática do aborto, a qual foi publicada por uma revista de grande circulação ${ }^{21}$.

20 SCHOUPPE, Jean-Pierre. The right to conscientious objection of medical practitioners. The institutional dimension of the conscientious objection. United Nations Human Rights Council, Session 31, Genova. Disponível em: <http://9afb0ee4c2ca3737b892e804076442d956681ee1e5a58d07b27b.r59.cf2.rackcdn.co $\mathrm{m} /$ ECLJ\%20Docs/The\%20right\%20to\%20conscientious\% 20objection\%20of\%20medical\%20practitioners, \%20Prof. $\%$ 20Jean-Pierre\%20Schouppe.pdf $>$. Acesso em 31/01/2017.

21 TRIBUNAL EUROPEU DE DIREITOS HUMANOS. Application n. 12242/86, by Maximilian ROMMELFANGER against Federal Republic of Germany. Disponível em: $<$ http://csc.ceceurope.org/fileadmin/filer/csc/Human_Right s/SSHR/ROMMELFANGER_v._THE_FEDERAL_REPU BLIC_OF_GERMANY.pdf >. Acesso em 01/02/2017. 
O hospital empregador, tomando conhecimento do fato, dispensou o empregado por justa causa em razão do mesmo ter assinado a carta defendendo o aborto.

Irresignado, o autor ajuizou uma reclamatória trabalhista em face do hospital alegando que sua dispensa havia sido discriminatória. Em primeiro e segundo grau, os tribunais alemães entenderam que a dispensa era ilegal visto que o direito à liberdade de consciência do empregado deveria prevalecer sobre o direito do empregador. No entanto, em última instancia, a Corte Constitucional Federal Alemã reformou integralmente as decisões proferidas, fundamentando que, de acordo com a lei eclesiástica existente desde sua criação, o aborto é um crime gravíssimo que corrobora na automática excomunhão de um fiel e, sob este aspecto, o fato do empregado defender tal prática acarreta em uma automática quebra de contrato, além de afetar a credibilidade da própria igreja, dando ensejo à dispensa por justa causa.

Tendo a decisão transitado em julgado, restou ao empregado o ajuizamento da ação perante o Tribunal Europeu de Direitos Humanos, arguindo violação ao seu direito de liberdade de expressão garantido pelo artigo $10^{\circ}$ da Convenção. O Tribunal, seguindo a decisão da Corte Constitucional Federal Alemã, julgou improcedente a ação argumentando que, se o empregador é uma organização baseada em certas convicções e valores, dos quais considera essenciais para a realização de suas funções na sociedade, então deve gozar do direito de exercer, assim como o empregado, da sua liberdade de expressão como empregador.

Entendeu, ainda, que um empregador desta natureza não consegue exercer amplamente suas funções se não impor algumas obrigações de lealdade aos seus empregados.
Os Tribunais da Suíça ${ }^{22}$ e Itália $^{23}$ também já foram instados a se manifestar em reclamatórias trabalhistas envolvendo professores ativistas da igreja Universal empregados de uma escola infantil evangélica. Também, nestes casos, o Tribunal Europeu de Direitos Humanos entendeu que o direito da escola de dispensar os empregados era lícito, pois os valores dos mesmos eram incompatíveis com a empregadora, ensejando a quebra de contrato por ausência de confiança.

O julgado mais recente proferido pelo Tribunal Europeu de Direitos Humanos invocou o instituto das organizações de tendência para justificar a sua decisão em um caso envolvendo a renovação de um contrato de trabalho de um professor de religião espanhol.

A ação foi ajuizada pelo o espanhol José Antônio Fernández Martínez, em face do Reino da Espanha perante o Tribunal Europeu de Direitos Humanos ${ }^{24}$.

Em apertada síntese, em 1961 o demandante foi ordenado sacerdote, sendo que em 1984 solicitou ao Vaticano a dispensa do voto de celibato, não obtendo resposta. No ano seguinte contraiu núpcias, tendo concebido com sua esposa cinco filhos. Em 1991 foi contratado pelo Instituto Público da Comunidade Autônoma de Murcia para lecionar religião e moral católica, cujo contrato de empregado era anual e

22 TRIBUNAL EUROPEU DE DIREITOS HUMANOS. Abaz Dautaj x Suíça, n. 32166/05. Disponível em: $<$ http://relevancy.bger.ch/php/clir/http/index.php?lang=fr\& zoom=\&type=show_document\&highlight_docid=cedh $\% 3$ A\%2F\%2F20070920_32166_05\%3Afr>. Acesso em 01/02/2017.

23 Tribunal Europeu de Direitos Humanos. Lombardi Vallauri x Itália, n. 39128/05. Disponível em: <http://www.camera.it/application/xmanager/projects/leg1 7/attachments/sentenza/testo_integrale_sentenzas/000/000/ 313/LOMBARDI_VALLAURI.pdf $>$. Acesso em 01/02/2017.

24 TRIBUNAL EUROPEU DE DERECHOS HUMANOS. Gran Sala. Asunto Fernández Martínez e. España. Demanda n. 56080/07. Estrasburgo, 2014. Disponível em: <http://relapt.usta.edu.co/images/Caso-FernandezMartinez-STEDH-Junio-2014.pdf>. Acesso 14/01/2017. 
renovável. Ao longo da relação contratual participou ativamente de movimentos e publicou artigos que defendiam o "pró-celibato opcional", além de expor abertamente sua situação familiar de sacerdote casado e pai de família, inclusive concedendo entrevistas a respeito.

Posteriormente, em 1997, a solicitação de dispensa do celibato do demandante foi aceita, isentando-o das obrigações e retirando a condição clerical. Ocorre que, sem a condição clerical, o demandante não mais poderia ensinar religião católica em estabelecimentos públicos, tendo sido, então, dispensado.

$\mathrm{O}$ demandante se insurgiu contra a decisão de forma administrativa e judicial em nível nacional, alegando violação do seu direito à liberdade de expressão e crença, além de afronta ao seu direito à proteção da vida privada, todas sem sucesso, tendo o Tribunal Superior de Justiça de Murcia se pronunciado no sentido de que o vínculo estabelecido entre o professor e a Igreja se baseava em uma relação de confiança não sendo uma relação neutra ${ }^{25}$, cabendo ao padre cumprir suas obrigações de acordo com o Código de Direito Canônico.

Irresignado com as decisões judiciais nacionais, ingressou com a demanda perante o Tribunal Europeu de Direitos Humanos, o qual tratou a questão igualmente como uma colisão de direitos, ponderando em sua decisão através da harmonização de direitos que: (a) a interação entre a vida privada e a vida profissional no presente caso exige não apenas capacidades técnicas, mas também a capacidade de seguir a doutrina da igreja, criando assim um vínculo

\footnotetext{
25 Consta do julgado: “(...) La enseñanza en cuestión responde a la doctrina de una religión - La Católica (...) Por lo tanto el vínculo establecido entre el profesor y el Obispo se basa en una relación de confianza. Por tanto, no se está en presencia de una relación jurídica neutra, como podría ser la de un ciudadano sin más con los poderes públicos. Restringiendo todavía más el campo operativo, estamos situados en un punto fronterizo entre lo que es la pura dimensión eclesiástica y lo que es el comienzo, en su
} caso, de la relación laboral". direto entre o comportamento da vida privada e da atividade profissional; (b) que a opção escolhida pelo demandante para com a sua vida privada e familiar comprometeu gravemente as possibilidade de exercer sua atividade profissional específica; que não cabe ao Estado fazer prevalecer o direito do demandante a vida privada sobre os direitos da Igreja Católica, tanto que que o princípio da autonomia religiosa pró́be o estado de obrigar uma comunidade religiosa de admitir ou dispensar um indivíduo; (c) que a natureza do posto ocupado pelo demandante, professor de religião católica, é uma atividade crucial que exige do empregado uma obrigação de lealdade particular; (d) que o fato do demandante ter voluntariamente se exposto à entrevistas e fotos com a família durante os movimentos que participou quebrou o vínculo de confiança especial que era necessário para cumprir as tarefas que lhe incumbia.

Em suma, o Tribunal Europeu de Direitos Humanos concluiu que não era irrazoavel que a comunidade religiosa exigisse de seus professores de religião uma lealdade particular, na medida em que são considerados seus representantes e, assim sendo, a existência de divergências entre as ideias do empregado pode gerar um problema de credibilidade quando este milita ativa e publicamente contra os ideais daquela organização. Noutras palavras, a limitação do direito à vida privada do empregado não foi considerada desproporcional e, portanto, a dispensa foi legitima.

Os julgados demonstram que o conceito em análise está consolidado pela doutrina e jurisprudência europeia, muito em razão da promulgação das Diretivas promulgadas, que vincularam os Estados-Membros à concretização de um determinado objetivo ${ }^{26}$ que, no presente caso, foi a harmonização das ordens jurídicas

26 FREIRE, Paula Vaz. Diretiva da união europeia. Disponível em: <http://aprenderamadeira.net/diretiva-dauniao-europeia/>. Acesso em 02/02/2017. 
nacionais com o direito da própria União Europeia a respeito do instituto jurídico das Empresas de Tendência.

Com a uniformização do entendimento pelos Estados-Membros, gerou-se um nível de integração maior entre eles, sendo esta a principal razão da criação da própria União Europeia.

\section{MERCOSUL}

Diferentemente da União Europeia, o Mercosul não goza de Diretivas que orientem os países membros e/ou os vincule em como proceder quando diante de conflitos envolvendo empresas de tendência, tampouco prevê em seus instrumentos constitutivos algo neste sentido.

A Declaração Sociolaboral do Mercosul estabelece que todo empregado tem garantido o direito a igualdade de direitos, tratamento e oportunidades, sem distinção ou exclusão por motivo de raça, credo, opinião política, sindical, ideologia, etc. ${ }^{27}$. De modo diverso, assegura ao empregador o direito de organizar e dirigir a empresa, em conformidade com as legislações e as práticas nacionais ${ }^{28}$.

Observa-se que a Declaração não abre brechas para uma interpretação indireta e/ou extensiva do instituto jurídico das empresas de tendência. Pelo contrário, é enfática ao afirmar que nenhum empregado poderá ter seus direitos retalhados em prol da empresa onde está inserido.

Por via de consequência, os tribunais trabalhistas dos Estados-Membros vivem em um limbo de incertezas e inseguranças jurídicas quando a controvérsia se cinge acerca da

\footnotetext{
27 MERCOSUL. Declaração Sociolaboral do Mercosul. Artigo $\quad 1^{\circ}$ Disponível em: <http://www.tprmercosur.org/pt/tal.htm>. Acesso em 05/02/2017.

${ }^{28}$ MERCOSUL. Declaração Sociolaboral do Mercosul. Artigo $\quad 7^{\circ}$. Disponível em: <http://www.tprmercosur.org/pt/tal.htm>. Acesso em 05/02/2017.
}

integração de ideologias dentro do ambiente de trabalho.

Com exceção da Argentina, onde o tema é tratado com certo amadurecimento pelos tribunais, nos demais países membros a questão dificilmente é abordada de modo adequado, sendo que por vezes é ignorada por completo, implicando no descumprimento do artigo $1^{\circ}$ do Tratado de Assunção ${ }^{29}$ que imputa aos países o dever de harmonizar as legislações para fortalecer $\mathrm{o}$ processo de integração, de desenvolvimento econômico e justiça social.

Registre-se, por fim, que o Tribunal Administrativo-Trabalhista do Mercosul, criado para resolver os conflitos administrativos laborais de funcionários do Mercosul, com sede em Assunção, até o presente momento não julgou nenhum caso invocando o instituto jurídico das empresas de tendência ${ }^{30}$.

Por uma questão metodológica, optouse por abordar os países integrantes do Mercosul na ordem do mais evoluído no que concerne a aplicação do conceito em análise (Argentina), ao menos (Paraguai), sendo o que passa a expor.

\subsection{ARGENTINA}

Comparativamente aos demais países membros integrantes do Mercosul, a Argentina é a mais vanguardista na interpretação e aplicação do instituto jurídico das empresas de tendência, havendo alguns poucos tribunais que ainda insistem em ignorá-la.

Em linhas gerais, o ordenamento jurídico argentino prevê diversos dispositivos constitucionais que intentam inibir condutas discriminatórias dentro do ambiente de trabalho, além de garantir a preservação do direito à

\footnotetext{
${ }^{29}$ MERCOSUL. Tratado de Assunção, 1991.

${ }^{30}$ MERCOSUL. Tribunal Administrativo Trabalhista do Mercosul. Disponível em: $<$ http://www.tprmercosur.org/pt/tal.htm>. Acesso em 05/02/2017.
} 
intimidade e privacidade do empregado ${ }^{31}$. De outro turno, assegura ao empregador o direito de gerir o negócio da maneira que melhor lhe convir, podendo inclusive alterar as condições contratuais contanto que haja de maneira razoável e que tal conduta não implique em perda desarrazoada para o empregado ${ }^{32}$.

Existe, ainda, a previsão de algumas leis argentinas que facultam às empresas o exercício do direito à objeção de consciência em razão de questões ideológicas, das quais se destacam duas: (1) A primeira delas, n. 25.673/2002 ${ }^{33}$, assegura as instituições educativas públicas de gestão privada, confessionais ou não, o direito de se absterem de lecionar a respeito de saúde reprodutiva acaso tal ensinamento fira as suas convicções; (2) A segunda lei, n. 26.150/2006 ${ }^{34}$, estabelece que cada instituição escolar incluirá em seu projeto institucional aquilo que se adaptar ao seu ideário institucional e as convicções de seus membros.

Diante deste breve panorama, verificase que o ordenamento jurídico argentino, apesar de assegurar diversos direitos aos empregados, estabelece tantos outros aos empregadores, especialmente no que concerne ao pleno exercício do direito à objeção de consciência destes, sendo um campo fértil para a aplicação o instituto ora em análise.

${ }^{31}$ ARGENTINA. Constitución Nacional Argentina, 1994. Artigos 14 e 17 . Disponível em: <http://pdba.georgetown.edu/Constitutions/Argentina/arge n94.html>. Acesso em 15/01/2017.

1994.

32 ARGENTINA. Ley do Contrato de Trabajo, 1976. Artigos 64, 65, 66 e 242. Disponível em: <http://servicios.infoleg.gob.ar/infolegInternet/anexos/250 00-29999/25552/texact.htm>. Acesso em 15/01/2017.

33 ARGENTINA. Lei 25.673 de 2002. Artigos 9 e 10 Disponível

em:

<http://www.msal.gob.ar/saludsexual/ley.php>. Acesso em 16/01/2017.

34 ARGENTINA. ARGENTINA. Lei 25.170 de 2006. Artigo 5.5 Disponível em: <http://servicios.infoleg.gob.ar/infolegInternet/anexos/120 000-124999/121222/norma.htm>. Acesso em 15/01/2017.
A respeito, Carlos Alberto Livellara, ao tratar da aplicação das empresas de tendência no país, afirma ser possível a flexibilização de determinados direitos trabalhistas dos empregados, como por exemplo o questionamento à um candidato com relação a sua ideologia, desde que tal informação seja imprescindível para a atividade que exercerá ${ }^{35}$.

Também neste sentido, César Arese ${ }^{36}$ defende a aplicação do instituto jurídico no direito interno, conceituando-o como qualquer empresa que vise essencialmente a difusão de uma posição ideológica política, religiosa, sindical, artística, informativa ou cultural.

Inobstante, como nos demais países, a aplicação do instituto jurídico das empresas de tendência implica em um campo de conflito no próprio ordenamento jurídico interno, qual seja: de um lado (empregador), que tem a prerrogativa de gerenciar os meios de trabalho e exercer o direito à objeção da consciência por razões ideológicas e, de outro, (empregado) que goza da irrestrita proteção ao seu direito à intimidade e à vida privada.

Diante da controvérsia, os tribunais argentinos fundamentam suas decisões a partir da ponderação dos princípios e dos direitos mitigados do caso concreto, além de frequentemente invocar o direito comparado europeu, a exemplo do caso que passa a expor.

A Câmara do Trabalho da Segunda Circunscrição Judicial do Rio Negro, Argentina $^{37}$, foi instada a proferir decisão em

${ }^{35}$ LIVELLARA, Carlos Alberto. Derecho fundamental del trabajador inespecíficos: su problemática y application en Argentina. Revista Gaceta Laboral. Vol. 21, n. 1 (2015). Universidad del Zulia. Disponível em: <http://www.redalyc.org/pdf/336/33641802002.pdf>.

Acesso em 02/02/2017.

${ }^{36}$ ARESE, César. Motivos de ideología parte especial: Empresas de tendencia. Información jurídica inteligente, V/lex Argentina. Disponível em: $<$ http://ar.vlex.com/vid/motivos-ideologia-especialtendencia-468860>. Acesso em 02/02/2017.

${ }^{37}$ ARGENTINA. Província de Río Negro. Protocolo de los organismos del poder judicial. Numero expediente: 2CT- 
uma reclamatória trabalhista movida por um empregado - dispensado sem justa causa - em face da Associação Argentina dos Adventistas do Sétimo Dia, cuja lide se cingia a respeito da suposta discriminação religiosa sofrida pelo empregado durante a relação laboral.

Em apertada síntese, o reclamante, adventista, fora contratado para lecionar música, inglês e religião no Instituto Adventista Villa Regina. Ao longo da relação de emprego, deixou de efetuar o pagamento do dízimo porque seu filho havia contraído uma doença cujo tratamento prejudicou a sua situação financeira, sendo que nunca mais voltou a efetuar o pagamento de tal verba.

Posteriormente, ingressou como aluno em uma universidade pública para cursar pósgraduação, onde a maioria das aulas eram ministradas aos sábados - dia destinado a guarda do descanso religioso conforme as crenças adventistas. Somado a isto, ausentou-se de diversas atividades organizadas pela Associação Adventista, nas quais deveria obrigatoriamente comparecer em razão da sua situação como docente na reclamada.

Decorrido certo tempo, a Instituição Privada Adventista (reclamada), não tendo mais interesse na manutenção do vínculo empregatício, rescindiu o contrato do empregado, na forma de dispensa sem justa causa. Irresignado com a dispensa, o empregado ajuizou uma demanda trabalhista em face da instituição alegando ter sido vítima de discriminação religiosa supostamente por não

19652-07. Carátula: Castillo Franco David Enrique c/ Asociacion Argentina de Los Adventistas del Septimo Dia. Fecha: 21/12/2010. Disponível em: <http://www.jusrionegro.gov.ar/inicio/jurisprudencia/ver.p rotocolo.php?id=26101\&txt_nro_expediente=\&txt_caratul a=\&cbo_desde_dia=1\&cbo_desde_mes $=1 \&$ cbo_desde_ani o=1990\&cbo_hasta_dia=7\&cbo_hasta_mes $=5 \&$ cbo_hasta _anio=2999\&txt_nro_sentencia=\&cbo_tipo_sentencia $=-$ $1 \&$ txt_sentencia $=\&$ cbo_organismo $=-1>$. Acesso em $12 / 01 / 2017$. efetuar o pagamento do seu dízimo e exercer atividades aos sábados (pós-graduação).

Em primeiro grau a ação foi julgada improcedente, tendo o juiz prolator da sentença invocado o instituto jurídico das empresas de tendência para fundamentar sua decisão argumentando que, inobstante o empregado ter assegurado o seu direito à privacidade e à vida íntima, por estar inserido em instituição religiosa que prega valores amplamente reconhecidos, notadamente empresa de tendência, além de exercer o cargo de professor de religião, era esperado dele um comportamento em consonância com os padrões de ética e moral da organização.

Em sede recursal a sentença de improcedência foi integralmente mantida pela Câmara de Trabalho da Segunda Circunscrição Judicial, a qual entendeu que, em razão da reclamada (Associação Argentina dos Adventistas do Sétimo Dia) se tratar de uma empresa de tendência, a conduta do empregado de exercer atividades aos sábados e deixar de efetuar o pagamento do dízimo colocaram seriamente em jogo a credibilidade da instituição, razão pela qual a dispensa não poderia ser considerada discriminatória.

Argumentou, ainda, que o docente encarregado de ensinar religião, ao contrariar os ditames da fé através do seu mau comportamento, deixou a Instituição religiosa à mercê de críticas. Veja-se abaixo extrato do julgado:

En conclusión, la demandada inmersa dentro del sistema educativo, ofrece a la sociedad otra opción, esto es, una educación que además de cumplir con los planes oficiales de estudio tiene una orientación religiosa arraigada dentro de los postulados de la fe Adventista. En este contexto, sugerir a la plana docente que adecuen conductas personales consideradas disvaliosas con los principios morales y mandatos religiosos que la institución inculca, no implica llevar adelante conductas discriminatorias, sino por el contrario, procurar con ello una coherencia con el modelo educativo. Calificar de discriminatoria una actitud en tal sentido, derivaría 
no solo en la imposibilidad de llevar adelante un proyecto educativo con la impronta en el credo Adventista, pues implica dejar sin contenidos los valores y principios inculcados, sino que también, implicaría lesionar el derecho de la institución de proponer una opción académica diferente. No estamos frente a un caso en donde se imponga o se exija a la plana docente convertirse a la fe Adventista o se discrimine a algún educador por tener una orientación religiosa diferente, sino en presencia de un profesor adventista que no cumplió con los mandatos bíblicos de la fe que dice profesar y que se le sugirió que adopte una conducta consecuente con su propia inclinación religiosa, que además, coincidía con la de la Institución. De manera que no observo ni trato discriminatorio ni despido discriminatorio [...].

O julgado proporciona um entendimento e um panorama geral a respeito de como o instituto é aplicado e qual o conflito jurídico que ele cria dentro do ordenamento jurídico argentino.

Conclui-se que no país o conceito foi recepcionado pela doutrina e jurisprudência, havendo pouquíssimos registros de insurgência com relação a sua aplicação, o que torna a Argentina o país mais desenvolvido no que concerne ao instituto em análise no âmbito do Mercosul.

\subsection{BRASIL}

Diferentemente da Argentina, onde o assunto goza de certo amadurecimento e reconhecimento nos tribunais, no Brasil a questão ainda é tratada com bastante divergência, muito em razão do protecionismo exacerbado da legislação trabalhista brasileira para com o trabalhador.

A Constituição de 1988 e a Consolidação das Leis do Trabalho estabelecem inúmeras prerrogativas aos empregados, a exemplo do direito à privacidade, intimidade, inviolabilidade da vida íntima, etc., e algumas poucas aos empregadores, a exemplo o poder diretivo, que é bastante limitado. Existem, ainda, leis específicas promulgadas que proíbem o empregador de limitar qualquer direito do empregado relacionado a questões de foro íntimo, que é o caso da Lei 9.029 de $1995^{38}$.

$\mathrm{O}$ ordenamento, engessado, dificulta a aplicação do instituto jurídico das empresas de tendência e, apesar de existirem julgamentos que defendem a aplicação do tema, o conservadorismo e positivismo tende a prevalecer nos tribunais pátrios.

Por via de consequência, a figura do empregador de tendência não é reconhecida pelo ordenamento jurídico brasileiro e, apesar de ser possível invocar as Diretivas da Comunidade Europeia ${ }^{39}$ como um direito comparado, conforme autoriza $\mathrm{o}$ artigo $8^{\circ}$ da Consolidação das Leis do Trabalho ${ }^{40}$, na prática os juízes do trabalho não costumam assim proceder. É o que se observa quando se analisa os julgados a respeito do tema.

No objetivo de fazer uma análise comparada entre a Argentina e o Brasil, optou-se por expor um julgado de um caso análogo ao exposto acima, que envolve o pagamento de dízimos por empregados de organização religiosa, para demonstrar a divergência com que o tema é tratado pelos países mercosulinos.

O Tribunal do Trabalho da $9^{a}$ Região ${ }^{41}$ foi instado a proferir decisão em uma reclamatória trabalhista ajuizada por um ex empregado dispensado sem justa causa, em face de uma organização religiosa.

38 BRASIL. Lei 9.029/1995. Artigo $1^{\circ}$ Disponível em: <http://www.planalto.gov.br/cCivil_03/LEIS/L9029.HTM $>$. Acesso em 04/02/2017.

39 GARCEZ, José Maria Rossani. Curso de Direito Internacional Privado. Rio de Janeiro: Revista Forense, 1999.

${ }^{40}$ BRASIL. Consolidação das Leis do Trabalho. Artigo $8^{\circ}$. Disponível em:

<http://www.planalto.gov.br/ccivil_03/decretolei/Del5452.htm>. Acesso em 06/02/2017.

${ }^{41}$ BRASIL. Poder Judiciário Federal Justiça do Trabalho, Tribunal Regional do Trabalho da 9 Região, 4 Vara do Trabalho de Curitiba - PR. Processo n. 37430-2013-00409-00-6. Data do julgamento: 10/10/2014. 
Em síntese, alegava o reclamante, coordenador de ensino da Igreja, ter sido vítima de discriminação por não efetuar periodicamente o pagamento dos dízimos, o que corroborou na perda da sua "Recomendação Para o Templo" e, posteriormente, na sua velada dispensa sem justa causa.

A organização religiosa, em defesa, alegou que como o autor era membro e empregado de uma instituição ultraconservadora, deveria manter um padrão de conduta mais elevado e adequado aos interesses e valores éticos e morais da igreja, deixando de praticar condutas que prejudicassem a imagem da mesma. Afirmou ainda que a perda da recomendação para o templo ocorreu após o encerramento do contrato e apenas em razão do reclamante não estar vivendo os ensinamentos da igreja quanto ao respeito ao convívio familiar, especificamente em relação ao tratamento dedicado à esposa.

Em primeiro grau, a ação foi julgada procedente tendo o juiz da causa entendido que "na medida que a ré exigia, o dízimo não era mais oferta, mas sim taxa e não estava previsto no ato constitutivo da entidade associativa qualquer taxa" e mais, que o reclamante era duplamente punido: como membro da igreja e como empregado ${ }^{42}$.

Em sede de recurso interposto pela reclamada, o Tribunal do Trabalho da $9^{\text {a }}$ Região confirmou a decisão de primeiro grau, considerando a dispensa discriminatória, condenando a organização ao pagamento de indenização por dano moral e afirmando que "restou demonstrado que a igreja, valendo-se de sua autoridade eclesiástica e de empregadora, impunha a obrigação de que o autor lhe

\footnotetext{
${ }^{42}$ BRASIL. Poder Judiciário Federal Justiça do Trabalho, Tribunal Regional do Trabalho da 9 Região, 4 Vara do Trabalho de Curitiba - PR. Processo n. 37430-2013-00409-00-6. Data do julgamento: 10/10/2014.
}

repassasse $10 \%$ dos seus ganhos, exercendo reprimenda moral e coação espiritual [...]"43.

Registre-se que o julgado sequer cita o instituto jurídico das empresas de tendência, negando-se a utilizar o direito comparado para fundamentar a sua decisão e fazendo uma aplicação da lei em sentido estrito.

De outro turno, em um outro julgado, proferido desta vez pelo Tribunal do Trabalho da

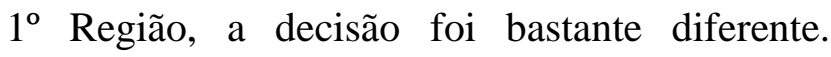
Tratava-se de uma reclamatória trabalhista movida por um empregado dispensado por justa causa, ocupante do cargo de gerente do Centro de Recursos de Empregados da empregadora, organização religiosa (ré).

Em síntese, alegava o empregado que a dispensa havia sido discriminatória, fundamentada no fato dele ter sido excomungado das leis e da ordem da igreja.

A reclamada, em sua defesa, alegou que a dispensa seria legal porque o comportamento do reclamante fora denunciado como assédio por uma das voluntárias, além de outras também terem descrito o comportamento do mesmo como abusivo. A reclamada ainda invocou o instituto das empresas de tendência, o que garantiria a prerrogativa de exigir de seus colaboradores que observem os padrões éticos e morais da empresa.

A demanda foi julgada improcedente, tendo o juízo entendido que o reclamante "exercia função que estava intrinsicamente ligada à tendência ou ideologia da organização da reclamada, era necessária a conformação do ideário particular com os objetivos sociais defendidos pela igreja, já que o cumprimento das

43 BRASIL. Poder Judiciário da Justiça do Trabalho, Tribunal Regional do Trabalho da 9 Região. N. do processo TRT: 37430-2013-004-09-00-6 (RO). Data do julgamento: 08/10/2015. 
tarefas, nesse caso, significava a própria expressão das ideias da organização"44.

O reclamante recorreu da decisão, sem lograr êxito na tentativa de reforma, tendo inclusive o Tribunal entendido que "notadamente pela natureza da instituição, religiosa, com clausula de conduta expressa no contrato de trabalho, bem como de conflito de interesses, além do confessado conhecimento da ideologia e ética exigidas" 45 , correta a justa causa aplicada ao reclamante.

Da análise dos julgados se verifica que os tribunais brasileiros ainda divergem muito com relação a aplicabilidade do instituto das empresas de tendência, por vezes o invocando para justificar uma dispensa por justa causa, por outras o ignorando para caracterizar uma dispensa discriminatória.

Conclui-se que, apesar do ordenamento jurídico interno possibilitar o uso do direito comparado quando não há previsão legal interna a respeito, notadamente o caso das empresas de tendência, na prática tal situação é pouco presenciada.

A verdade é que a divergência com relação a aplicação do conceito dentro do próprio território nacional é tamanha, que existem julgados proferidos pelo mesmo tribunal que acabam prolatando decisões em sentidos opostos, por vezes aplicando o instituto e, por vezes, negando-o.

Em suma, o Brasil carece de regulamentação a respeito da matéria, sendo palco de divergências no que concerne a aplicação do conceito que ainda está sendo delineado $^{46}$.

\footnotetext{
${ }^{44}$ Poder Judiciário, Justiça do Trabalho, Tribunal Regional do Trabalho da 1 Região. N. processo: 000133911.2011.5.01.0016. Data do julgamento: 05/08/2015.

${ }^{45}$ Poder Judiciário, Justiça do Trabalho, Tribunal Regional do Trabalho da 1 Região. N. processo: 000133911.2011.5.01.0016. Data do julgamento: 05/08/2015.

${ }^{46}$ SETUBAL, Alexandre Montanha de Castro. Aspectos interdisciplinares e jurídico-trabalhista do direito fundamental à liberdade religiosa. Universidade Federal
}

\subsection{URUGUAI}

No Uruguai a questão carece de debate jurídico em comparação a Argentina e o Brasil. A verdade é que o instituto "empresa de tendência" é tratado de modo indireto e, ainda assim, embrionário por apenas duas leis uruguaias, promulgadas em 2012. Isto porque, assim como no Brasil, a legislação Uruguaia é exacerbadamente protecionista, sendo que a própria Constituição de 1967 reconhece aos empregados o direito à independência da sua consciência moral e cívica perante o contrato de trabalho ${ }^{47}$, sem qualquer ressalva. Por consequência, a previsão de tal norma dificulta a aplicação das empresas de tendência em uma eventual demanda trabalhista, jogando para escanteio a possibilidade de invocá-la.

De todo modo, a primeira lei, n. ${ }^{\circ} 18.473$ de $2012^{48}$, estabelece que o direito à objeção da consciência é um direito de todas as pessoas físicas e jurídicas, devendo ser entendido como o direito de não ser obrigado a agir contra suas próprias convicções. A segunda lei, n. ${ }^{\circ} 18.987$ de $2012^{49}$, legaliza a interrupção voluntária da gravidez até a décima segunda semana de gestação.

Conforme adiante se demonstrará, as empresas de tendência são tratadas indiretamente em alguns pontos das referidas leis, sendo que a segunda (aborto) se utiliza da primeira (objeção à

da Bahia, Salvador, 2011. Disponível em: <https://repositorio.ufba.br/ri/bitstream/ri/10721/1/Alexan dre.pdf>. Acesso em 01/02/2017.

${ }^{47}$ URUGUAI. Constituição de 1967. Artigo 54Disponível em: <http://www.conteudojuridico.com.br/vade-mecumestrangeiro,constituicao-do-uruguay-constitucion-deluruguay-de-1967-con-reformas-de-1996,20997.html> . Acesso em 20/01/2017.

${ }^{48}$ URUGUAI. Lei n. ${ }^{\circ} 18.473$ de 2012. Disponível em: <http://testamentovital.com.br/legislacao/uruguai/>.

Acesso em 22/01/2017.

${ }^{49}$ URUGUAI. Lei n. ${ }^{\circ} 18.473$ de 2012. Disponível em: <http://testamentovital.com.br/legislacao/uruguai/>. Acesso em 22/01/2017. 
consciência) para adentrar em questões de particular relevância para o presente estudo, conforme se demonstrará.

$\mathrm{O}$ artigo 10 da lei que legaliza o aborto determina que todas as instituições integradas ao Sistema Nacional de Saúde do Uruguai têm a obrigação de cumprir com a lei, devendo promover condições e possibilitar que todas as cidadãs tenham acesso ao procedimento outrora legalizado.

No entanto, o mesmo artigo ressalta que as instituições que eventualmente tenham objeções ideológicas contra o aborto (ex. empresas de tendência de cunho religioso) e desde que sejam preexistentes a vigência da lei, poderão ajustar com o Ministério da Saúde Pública a escusa à realização do procedimento. Ainda, em relação as instituições médicas privadas anteriores à vigência da lei, estas poderão incluir em seus estatutos disposições que estabeleçam que não realizarão procedimentos de interrupção voluntária da gravidez.

Acaso as instituições objetoras tenham o seu pleito de objeção de consciência deferido (autorização par anão realizar o procedimento do aborto), deverão, ainda assim, assumir todos os gastos que o procedimento de interrupção acarretará, além de terem de celebrar convênios com instituições que se disponibilizem a fazer o procedimento $^{50}$, conforme determina a lei.

Ocorre que, garantir à uma instituição que se abstenha de realizar o aborto por questões ideológicas, mas, ao mesmo tempo, obrigue-a a arcar com todos os gastos do paciente que deseja realizar o procedimento é, no mínimo, uma incoerência legislativa. Se o objetivo é assegurar o livre exercício da consciência pelas pessoas jurídicas, condicionar tal exercício ao pagamento

\footnotetext{
${ }^{50}$ JAVIER, Juvenal M. Reflexiones sobre la objeción de conciencia e ideario en el Uruguay a partir de las leys 18.987 y 18.473. Revista de Derecho Público, ano 22, número 43, Agosto/2013, p. 33-56. Disponível em: <http://www.revistaderechopublico.com.uy/revistas/43/arc
} hivos/Juvenal.pdf>. Acesso em 17/01/2017. dos custos que incidirão por consequência do procedimento vai na contramão de tal objetivo.

A respeito, o jurista uruguaio Santiago Canamares Arribas se manifestou criticando o dispositivo, afirmando inclusive que não havia muita diferença entre realizar o procedimento que se considera moralmente ilícito e pagar para que outros o façam ${ }^{51}$.

Acredita-se que assiste razão o jurista. Analogamente, é o mesmo que absolver um mandatário de um crime de homicídio supostamente porque não foi ele quem tirou a vida de alguém, apenas deu ordens para que outro sujeito assim procedesse.

A referida lei ainda determina que as instituições que se abstenham a realizar o aborto por questões ideológicas, devem permitir que seus profissionais realizem o procedimento se para eles não houver reservas de consciência religiosas ou ideológicas. Com o devido respeito, parece outra inconsistência da lei, a qual ignora completamente o instituto jurídico das empresas de tendência, onde se poderia exigir de seus empregados condutas e obrigações de lealdade aos princípios daquela organização, limitando alguns direitos fundamentais, sob pena de dispensa por justa causa a depender do posto de trabalho ocupado por aquele empregado.

As instituições de saúde que se negam a realizar o aborto por motivos ideológicos não devem ser obrigadas a tolerar que tal procedimento seja realizado por um empregado desta instituição que seja a favor do aborto, conforme defende o jurista Santiago Canamares Arribas $^{52}$, cuja opinião se compartilha.

\footnotetext{
${ }^{51}$ ARRIBAS, Santiago Cañamares. El reconocimiento de la objeción de conciencia en el derecho uruguayo. Montevideo: Faculdad de Derecho de la Universidad Católica del Uruguay. Disponível em: $<$ http://ucu.edu.uy/sites/default/files/Estudios_Juridicos_1 2.pdf $>$. Acesso em 17/01/2017.

52 ARRIBAS, Santiago Cañamares. El reconocimiento de la objeción de conciencia en el derecho uruguayo. Montevideo: Faculdad de Derecho de la Universidad Católica del Uruguay. Disponível
} 
De modo diverso ao do jurista acima citado, o Colégio Médico do Uruguai emitiu em 2013 um comunicado à toda a comunidade médica e à opinião pública afirmando que o direito fundamental das mulheres ao abordo deveria prevalecer sobre o direito dos hospitais a objeção da consciência ${ }^{53}$.

Em razão das inúmeras divergências que surgiram, o Tribunal Contencioso Administrativo do Uruguai foi instado a se manifestar em uma ação coletiva movida pelos médicos que pleiteavam o seu direito à objeção da consciência, tendo proferido decisão no sentido de que o direito dos médicos à objeção da consciência é legal $^{54}$.

Apesar de não ter sido encontrado nenhum julgado que aplicasse o instituto jurídico das empresas de tendência, uma pequena parte da doutrina uruguaia tece breves considerações a respeito das empresas da tendência ou ideológicas com base nos dispositivos legais acima dispostos, tratando as próprias instituições médicas privadas confessionais como tal.

Registre-se, por derradeiro, que os juristas invocam a doutrina comparada para explicar o instituto, utilizando-se principalmente de julgados espanhóis que tratam do tema ${ }^{55}$.

Em suma, a maior parte dos juristas uruguaios defendem o instituto das empresas de

<http://ucu.edu.uy/sites/default/files/Estudios_Juridicos_1 2.pdf $>$. Acesso em 17/01/2017.

${ }^{53}$ CASTILLA, Gustavo Ordoqui. Aborto y la objeción de conciencia en el Uruguay, 2015. Disponível em: <http://www.guantor.com/assets/aborto-y-objecion-deconciencia-en-uruguay.pdf $>$. Acesso em 18/01/2017.

54 URUGUAI. Decretero de Sentencias, Montevideo, 2015. Alonso, Justo y otros. Disponível em: <www.tca.gub.uy/visornew.php?numero=586\&ano=2015 $>$. Acesso em 18/01/2017.

55 JAVIER, Juvenal M. Reflexiones sobre la objeción de conciencia e ideario en el Uruguay a partir de las leys 18.987 y 18.473. Revista de Derecho Público, ano 22, número 43, Agosto/2013, p. 33-56. Disponível em: <http://www.revistaderechopublico.com.uy/revistas/43/arc hivos/Juvenal.pdf>. Acesso em 17/01/2017. tendência, sendo que Pedro Montado ${ }^{56}$ afirma que a lei que regulamenta o aborto tem, primeiramente, eficácia nas instituições públicas, mas como estas não dão conta de todo o serviço, muitos recorrem as privadas. Neste caso, não podem as instituições de saúde privadas serem obrigadas a agirem contra a sua ideologia em razão da ineficiência dos serviços prestados pelo estado.

Deste modo, observa-se que o país carece de estudos jurídicos a respeito do tema, assim como no Brasil.

\subsection{PARAGUAI}

O derradeiro país mercosulino Paraguai, foi propositadamente deixado por último por ser o mais escasso no que concerne ao tratamento das organizações de tendência, não tendo a doutrina e a jurisprudência alcançado um nível de debate a respeito do tema.

A Constituição de 1992 reconhece o direito de todo cidadão paraguaio a exercer a objeção da consciência por razões éticas ou religiosas ${ }^{57}$. Estabelece, ainda, que os militares que arguirem o seu direito à objeção de consciência prestarão serviços alternativos ${ }^{58}$, existindo uma lei específica para tal profissão (lei 4013/2010).

De outro turno, apesar da Legislação Trabalhista $^{59}$ estabelecer que são obrigações dos

${ }^{56}$ MONTANO, Pedro J. Objeción de conciencia, 2016. Disponível em: <http://wold.fder.edu.uy/contenido/penal/montano_objecio n-de-conciencia.pdf>. Acesso em 18/01/2017.

57 PARAGUAI. Constituição de 1992. Artigo 37. Disponível em: <http://www.oas.org/juridico/mla/Sp/pry/sp_pry-int-textconst.pdf $>$. Acesso em 22/01/2017.

58 PARAGUAI. Constituição de 1992. Artigo 129. Disponível em: <http://www.oas.org/juridico/mla/Sp/pry/sp_pry-int-textconst.pdf $>$. Acesso em 22/01/2017.

${ }^{59}$ PARAGUAI. Lei Trabalhista. Artigo 65 Disponível em: <http://humanidades.uni.edu.py/wpcontent/uploads/2016/07/Ley-213-93-C\%C3\%B3digoLaboral.pdf>. Acesso em 06/02/2017. 
empregados realizar o trabalho para o qual foram contratados de acordo com as ordens de direção do empregado, não se vislumbra, na prática, situações em que o interesse do empregador se sobreponha aos de seus empregados.

A verdade é que o país se transformou em referência quanto ao direito à objeção de consciência de seus cidadãos, mas, no que concerne ao exercício de tal direito por pessoas jurídicas, como por exemplo as empresas de tendência, os juristas rechaçam qualquer possibilidade de equiparação.

Assim como ocorre no Uruguai, o país aparentemente caminha na contramão no que concerne ao exercício da liberdade de consciência das empresas. Atualmente, vem testemunhando uma série de manifestações populares no intuito de implementar nos planos de educação infantil o ensino a respeito educação sexual, independentemente da natureza da instituição educacional $^{60}$, cujo movimento é defendido inclusive pelo $\mathrm{MEC}^{61}$.

O principal problema que se observa se refere as escolas particulares de cunho religioso, que serão obrigadas a ensinar a educação sexual que vai contra os seus parâmetros de fé, sua legislação canônica própria, além de colocar em risco a própria organização. Isto porque, aqueles que matriculam seus filhos em tal instituição, o fazem porque acreditam que as diretrizes de ensino e educação devem ser interligadas com a de fé, notadamente a católica de acordo com o exemplo.

Negar vigência ao exercício do direito à consciência da pessoa jurídica é refutar a própria instituição que vê seu direito restringido em prol de outro.

60 JÓVENES pieden educación sexual escolar y ley antidiscriminación. Disponível em: <http://www.paraguay.com/nacionales/jovenes-pideneducacion-sexual-escolar-y-ley-antidiscriminacion136133>. Acesso em 05/02/2017.

${ }^{61}$ Nivel inicial - PARAGUAI. MEC. Disponível em: <www.mec.gov.py/cms_v2/adjuntos/5831>. Acesso em 05/02/2017.
Conclui-se que o Paraguai é o país do Mercosul que mais carece de debate jurídico a respeito das empresas de tendência, não havendo qualquer julgado da Corte de Apelações Laborais ${ }^{62}$ que tenha arguido o instituto jurídico para fundamentar uma decisão.

\section{CONCLUSÃO}

O estudo objetivou analisar a aplicação do instituto jurídico das "Empresas de Tendência" na União Europeia e no Mercosul, utilizando-se para tanto da análise de julgados e do entendimento doutrinário em cada bloco.

Conforme exposto, a União Europeia domina o conceito e o aplica em seus julgados com precisão cirúrgica, havendo pouquíssima divergência a respeito do tema, muito em razão da existência de duas Diretivas que, ao vincular os países a atingir os objetivos nelas dispostos a respeito do tratamento quanto as empresas de tendência, corroborou na harmonização das próprias ordens jurídicas internas nacionais.

Em sede de Mercosul, como não há previsão a respeito do conceito nos protocolos e declarações, a análise acerca do tema foi realizada com base em cada Estado-Membro. Verificou-se que, diferentemente da União Europeia, no Mercosul o tema é tratado com bastante divergência, sendo que por vezes em um único país a controvérsia é tamanha que um mesmo tribunal regional profere decisões em sentidos opostos em lides envolvendo empresas de tendência.

Concluiu-se que a Argentina, o Brasil, o Uruguai e o Paraguai não são uníssonos com

${ }^{62}$ Foram realizadas pesquisas no site de busca "google" e nos tribunais laborais do país com os seguintes termos: "empresas de tendencia derecho paraguayo"; "derecho a objeción del consciencia derecho paraguayo"; "las organizaciones religiosas o ideológicas derecho paraguayo", "empresas ideológicas"; "despido por razones ideológicas"; "el derecho de objeción del empleador ideológico". 
relação a aplicação do conceito, distante, portanto de uma harmonização de legislações preconizadas no Tratado de Assunção, mas consoante com a ideia de intergovernabilidade, ainda em vigor no Bloco. A superação destas diferenças é uma necessidade, para lograr o fortalecimento do processo de integração.

Com vistas à experiência europeia, acredita-se a promulgação de diretivas ou protocolos no Mercosul traria consequências positivas para o bloco, promovendo a harmonização legislação de cada estado e, por via de consequência, corroborando numa maior integração entre eles.

Para tanto, propõe-se, também, a retificação do artigo 7 da Declaração Sociolaboral do Mercosul, atualmente na seguinte versão: “ $O$ empregador tem o direito de organizar e dirigir econômica e tecnicamente a empresa, em conformidade com as legislações e as práticas nacionais", para o fim de incluir o seguinte texto: "Sem prejuízo do disposto nos artigos 1 e 2, os Estados-Membros podem autorizar uma diferença de tratamento pelo empregador desde que, em virtude da natureza da atividade profissional na qual o empregado está inserido, essa característica constitua um requisito essencial, determinante e proporcional para o exercício de tal atividade".

A retificação, sem pretensão de solucionar todas as questões atinentes à vinculação de ideologias dentro do ambiente de trabalho, ao menos seria um passo importante para a harmonização futura das legislações dos Estados-Membros integrantes do Mercosul.

\section{REFERÊNCIAS}

ALEXY, Robert. Teoria dos direitos fundamentais. 2. ed. São Paulo: Malheiros Editores, 2011.

ARESE, César. Motivos de ideología parte especial: Empresas de tendencia. Información jurídica inteligente, V/lex Argentina. Disponível em: <http://ar.vlex.com/vid/motivos-ideologia-especialtendencia-468860>. Acesso em 02/02/2017.

ARGENTINA. Constitución Nacional Argentina, 1994. Disponível em: <http://pdba.georgetown.edu/Constitutions/Argentina/argen94.html>. Acesso em 15/01/2017.

Lei $25.170 \quad$ de $2006 . \quad$ Disponível em:

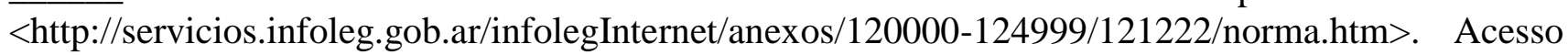
em 15/01/2017.

. Lei 25.673 de 2002. Disponível em: <http://www.msal.gob.ar/saludsexual/ley.php>. Acesso em 16/01/2017.

Ley do Contrato de Trabajo, 1976. Disponível em:

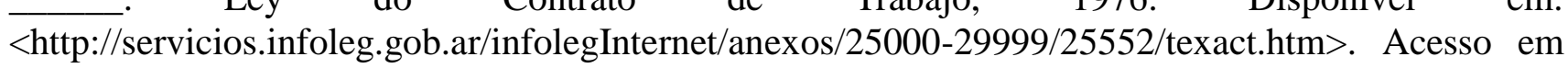
15/01/2017.

Província de Río Negro. Protocolo de los organismos del poder judicial. Numero expediente: 2CT-19652-07. Carátula: Castillo Franco David Enrique c/ Asociacion Argentina de Los Adventistas del Septimo Dia. Fecha: 21/12/2010. Disponível em: <http://www.jusrionegro.gov.ar/inicio/jurisprudencia/ver.protocolo.php?id=26101\&txt_nro_expedien te $=\&$ txt_caratula=\&cbo_desde_dia $=1 \&$ cbo_desde_mes $=1 \&$ cbo_desde_anio=1990\&cbo_hasta_dia $=7$ 
\&cbo_hasta_mes=5\&cbo_hasta_anio=2999\&txt_nro_sentencia=\&cbo_tipo_sentencia=1\&txt_sentencia=\&cbo_organismo=-1>. Acesso em 12/01/2017.

ARRIBAS, Santiago Cañamares. El reconocimiento de la objeción de conciencia en el derecho uruguayo. Montevideo: Faculdad de Derecho de la Universidad Católica del Uruguay. Disponível em: <http://ucu.edu.uy/sites/default/files/Estudios_Juridicos_12.pdf>. Acesso em 17/01/2017.

BOBBIO, Norberto. A era dos direitos. Rio de Janeiro: Elsevier, 2004.
BRASIL.
Lei
9.029/1995.
Disponível
em:

<http://www.planalto.gov.br/cCivil_03/LEIS/L9029.HTM>. Acesso em 04/02/2017.

. Poder Judiciário da Justiça do Trabalho, Tribunal Regional do Trabalho da 9 Região. N. do processo TRT: 37430-2013-004-09-00-6 (RO). Data do julgamento: 08/10/2015.

Poder Judiciário Federal Justiça do Trabalho, Tribunal Regional do Trabalho da 9 Região, 4 Vara do Trabalho de Curitiba - PR. Processo n. 37430-2013-004-09-00-6. Data do julgamento: $10 / 10 / 2014$.

Consolidação das Leis do Trabalho. Disponível em: <http://www.planalto.gov.br/ccivil_03/decreto-lei/Del5452.htm>. Acesso em 06/02/2017.

CARDO, Ivan Antonio Rodriguez. La incidencia de la libertad religiosa en la relación de trabajo desde la perspectiva del tribunal constitucional español. Direitos Fundamentais \& Justiça, n. 15, p. 17-39, abril/junho, 2011. Disponível em: <http://www.dfj.inf.br/Arquivos/PDF_Livre/15_Dout_Estrangeira_1.pdf>. Acesso em 31/01/2017.

CASTILLA, Gustavo Ordoqui. Aborto y la objeción de conciencia en el Uruguay, 2015. Disponível em: 〈http://www.guantor.com/assets/aborto-y-objecion-de-conciencia-en-uruguay.pdf >. Acesso em $18 / 01 / 2017$.

CORREA, Fernando Gustavo Abarca. Los derechos fundamentales del trabajador em la empresa. Universidade de Chile Faculdad de Derecho Departamento de Derecho Del Trabajo Y Seguridade Social. Disponível em: http://repositorio.uchile.cl/bitstream/handle/2250/107311/abarca_f.pdf?sequence=3. Acesso em 12/01/2017.

DWORKIN, Robert. Uma questão de princípio. 2. ed. São Paulo: Martins Fontes, 2005.

ESPANHA. Tribunal Constitucional da Espanha. STC 47/1985. Disponível em: <http://hj.tribunalconstitucional.es/es/Resolucion/Show/427>. Acesso em 05/02/2017.

FREIRE, Paula Vaz. Diretiva da união europeia. Disponível em: $<$ http://aprenderamadeira.net/diretiva-da-uniao-europeia/>. Acesso em 02/02/2017.

GALLEGO, Francisco Javier Calvo; LÓPEZ, María Fernanda Fernández. Directive 2000/78/EC and the proibition of discrimination based on religion. University of Sevilla and Huelva. Disponível em: $<$ http://www.era-comm.eu/oldoku/Adiskri/09_Religion/2005_CalvoGallego1-EN.pdf $\geq$. Acesso em 
23/01/2017.

GARCEZ, José Maria Rossani. Curso de Direito Internacional Privado. Rio de Janeiro: Revista Forense, 1999

JAVIER, Juvenal M. Reflexiones sobre la objeción de conciencia e ideario en el Uruguay a partir de las leys 18.987 y 18.473. Revista de Derecho Público, ano 22, número 43, Agosto/2013, p. 33-56. Disponível em: <http://www.revistaderechopublico.com.uy/revistas/43/archivos/Juvenal.pdf>. Acesso em 17/01/2017.

JÓVENES pieden educación sexual escolar y ley antidiscriminación. Disponível em: $<$ http://www.paraguay.com/nacionales/jovenes-piden-educacion-sexual-escolar-y-leyantidiscriminacion-136133>. Acesso em 05/02/2017.

LIVELLARA, Carlos Alberto. Derecho fundamental del trabajador inespecíficos: su problemática y application en Argentina. Revista Gaceta Laboral. Vol. 21, n. 1 (2015). Universidad del Zulia. Disponível em: <http://www.redalyc.org/pdf/336/33641802002.pdf> . Acesso em 02/02/2017.

MACHADO, Jónatas Eduardo Mendes. Liberdade religiosa numa comunidade constitucional inclusiva dos direitos da verdade aos direitos dos cidadãos. Coimbra: Coimbra Editora, 1996.

MERCOSUL. Declaração Sociolaboral do Mercosul. Disponível em: <http://www.tprmercosur.org/pt/tal.htm>. Acesso em 05/02/2017.

Tratado de Assunção. Disponivel em: <http://www.stf.jus.br/arquivo/cms/processoAudienciaPublicaAdpf101/anexo/Tratado_de_Assuncao. pdf>. Acesso em 20/01/2017.

- Tribunal Administrativo Trabalhista do Mercosul. Disponível em: <http://www.tprmercosur.org/pt/tal.htm>. Acesso em 05/02/2017.

MONTANO, Pedro J. Objeción de conciencia, 2016. Disponível em: $<$ http://wold.fder.edu.uy/contenido/penal/montano_objecion-de-conciencia.pdf $>$. Acesso em 18/01/2017.

ORGANIZAÇÃO INTERNACIONAL DO TRABALHO. Convenção $n .^{\circ} 111$. Disponível em: <http://www.oit.org.br/node/472>. Acesso em 15/01/2017.

PARAGUAI. Constituição $1992 . \quad$ de 1 em: <http://www.oas.org/juridico/mla/Sp/pry/sp_pry-int-text-const.pdf>. Acesso em 22/01/2017.

Lei Trabalhista. Disponível em: <http://humanidades.uni.edu.py/wpcontent/uploads/2016/07/Ley-213-93-C\%C3\%B3digo-Laboral.pdf>. Acesso em 06/02/2017. . MEC. Disponível em: <www.mec.gov.py/cms_v2/adjuntos/5831>. Acesso em 05/02/2017.

REIS, Raquel Tavares dos. Direitos, liberdades de garantias da pessoa do trabalhador despedido em 
razão da sua conduta extra-laboral. Revista Gestão e Desenvolvimento, 10 (2001), p. 95-127.

SÁNCHEZ, Belén Salanova. El principio de no discriminación por motivos religiosos y de convicción en el ámbito laboral: El acomodamiento razonable. Trabajo fim de master, 2013. Universidad Zaragoza. Disponível em: <http://zaguan.unizar.es/record/12435/files/TAZ-TFM-2013862.pdf>. Acesso em 14/01/2017.

SCHOUPPE, Jean-Pierre. The right to conscientious objection of medical practitioners. The institutional dimension of the conscientious objection. United Nations - Human Rights Council, Session 31, Genova. Disponível em: <http://9afb0ee4c2ca3737b892e804076442d956681ee1e5a58d07b27b.r59.cf2.rackcdn.com/ECLJ\%20Docs/The\%20right\%20to\%20 conscientious\%20objection\%20of\%20medical\%20practitioners,\%20Prof.\%20Jean-

Pierre\%20Schouppe.pdf>. Acesso em 31/01/2017.

SETUBAL, Alexandre Montanha de Castro. Aspectos interdisciplinares e jurídico-trabalhista do direito fundamental à liberdade religiosa. Universidade Federal da Bahia, Salvador, 2011. Disponível em: <https://repositorio.ufba.br/ri/bitstream/ri/10721/1/Alexandre.pdf>. Acesso em 01/02/2017.

TENA, Angel Luis de Val. Las empresas de tendencia ante el derecho del trabajo: libertad ideológica y contrato de trabajo. p. 179 . Disponível em: <http://dialnet.unirioja.es/servlet/articulo?codigo=229694>. Acesso em 22/09/2015.

TRIBUNAL EUROPEU DE DERECHOS HUMANOS. Gran Sala. Asunto Fernández Martínez e. España. Demanda n. 56080/07. Estrasburgo, 2014. Disponível em: <http://relapt.usta.edu.co/images/Caso-Fernandez-Martinez-STEDH-Junio-2014.pdf>. Acesso em 14/01/2017.

Abaz Dautaj x Suíça, n. 32166/05. Disponível em:

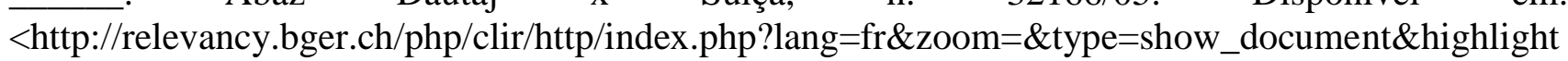
_docid=cedh\%3A\%2F\%2F20070920_32166_05\%3Afr>. Acesso em 01/02/2017.

Lombardi Vallauri $x$ Itália, n. 39128/05. Disponível em: <http://www.camera.it/application/xmanager/projects/leg17/attachments/sentenza/testo_integrale_sen tenzas/000/000/313/LOMBARDI_VALLAURI.pdf>. Acesso em 01/02/2017.

Application n. 12242/86, by Maximilian ROMMELFANGER against Federal Republic of Germany. Disponível em: <http://csc.ceceurope.org/fileadmin/filer/csc/Human_Rights/SSHR/ROMMELFANGER_v._THE_F EDERAL_REPUBLIC_OF_GERMANY.pdf >. Acesso em 01/02/2017.

UNIÃO EUROPEIA. Diretiva 94/45/CE do Conselho, de 22 de Setembro de 1994. Disponível em: <http://eur-lex.europa.eu/legal-content/PT/TXT/?uri=CELEX:31994L0045>. Acesso em 02/02/2017.

. Tratado sobre o funcionamento da União Europeia, 26/10/2012. Artigo 288: "A diretiva vincula o Estado-Membro destinatário quanto ao resultado a alcançar, deixando, no entanto, às instâncias nacionais a competência quanto à forma e aos meios". Disponível em: <http://eurlex.europa.eu/legal-content/pt/TXT/?uri=CELEX\%3A12012E\%2FTXT>. Acesso em 06/02/2017. 
URUGUAI. Constituição de 1967. Disponível em: <http://www.conteudojuridico.com.br/vademecum-estrangeiro,constituicao-do-uruguay-constitucion-del-uruguay-de-1967-con-reformas-de1996,20997.html>. Acesso em 20/01/2017.

Decretero de Sentencias, Montevideo, 2015. Alonso, Justo y otros. Disponível em: <www.tca.gub.uy/visornew.php?numero=586\&ano=2015>. Acesso em 18/01/2017.

. Lei n. ${ }^{\circ} 18.473$ de 2012. Disponível em: 〈http://testamentovital.com.br/legislacao/uruguai/>. Acesso em 22/01/2017.
Lei
n. ${ }^{\circ}$
18.987
de
2012.
Disponível
em:

<https://legislativo.parlamento.gub.uy/temporales/leytemp4933774.htm>. Acesso em 22/01/2017.

VIVES, Juan Martin. Las instituciones religiosas del tercer sector como empresas de tendencia. Revista de Estudos e Pesquisas Avançadas do Terceiro Setor (REPATS), Brasília, v. 1, n. 1, p.1-19, Jul-Dez, 2014.

Recebido em: 15/05/2017

Aceito em: 30/06/2017 
